\section{SELECTION OF SIR HENRY DALE'S PAPERS}

Adventures in Physiology

With Excursions into Autopharmacology. A Selection from the Scientific Publications of Sir Henry Hallett Dale. With an Introduction and Recent Comments by the Author. Pp. xvi+652. (London: Pergamon Press, Ltd., 1953.) $£ 6$ $6 s$.

IISTAMINE, acetylcholine and noradrenaline are powerful drugs and naturally present in the body ; discussions about them occupy a large proportion of the available time at meetings of the Physiological Society and the British Pharmacological Society. Drugs which oppose them or release them, enzymes which form them or destroy them and drugs which oppose the enzymes, can all be regarded as part of the subject of autopharmacology, which has provided the pharmacologists with a topic of general fundamental importance. Sir Henry Dale is both the father and the godfather of this subject. He was the first to recognize the importance of all these three substances and to make detailed studies of their actions, and he provided the subject with a name which is still less widely used than it might be.

A selection of thirty of Sir Henry's most important papers has now been published in a fine book with an introduction and recent comments on each paper by the author. The selection has been confined to those papers at the head of which Sir Henry's own name appears, and this limitation has led to the exclusion of papers from his laboratory to which he made important contributions without taking credit for them. There is, however, no lack of material, as is shown by the bibliography of 253 items included at the end of the book. The selected papers are those which have told exciting new chapters in two stories, the story of the chemical transmission of impulses at nerve endings and the story of the physiological function of histamine. Here are many famous tracings on smoked paper which are familiar in the text-books although their original source is not always realized. Here are new ideas, now generally accepted, put forward with the explicit clarity which made them immediately convincing. Here is an introduction which tells us how in 1904 Dr. Henry Dale at the age of twenty-nine decided to accept a research post under Mr. (later Sir) Henry Welleome, and of how so many other men who were later to become famous joined him there, and of the accidents which they turned into great opportunities. Mr. Wellcome said that he wanted work of permanent value to science to be done in his laboratories, but that he would also be grateful if the study of ergot could be rescued from the morass into which it had fallen. Both these wishes were triumphantly fulfilled when the study of ergot provided the inspiration for so many fundamental physiological discoveries.

"Adventures in Physiology" contains penetrating comments on each paper, which turn an anthology into a connected story, filling in gaps, adding human interest, and showing how the tale has unfolded in more recent years. These comments show that the author's brain is still more active than most other people's brains, and that he can still help to clear the thoughts of those who seek to follow in his footsteps. He has little to regret except that he did not always succeed in foreseeing what no one else foresaw; the few mistakes he has made have been turned to good advantage and provided clues for new advances.

The book is well produced and will be preserved in all medical libraries as a model of the way in which scientific discoveries should be made, and of the way in which scientific papers should be written. J. H. GadDum

\section{THE OUTPUT OF A UNIVERSITY}

\section{Alumni Cantabrigienses}

A Biographical List of all known Students, Graduates and Holders of Office at the University of Cambridge, from the Earliest Times to 1900. Compiled by Dr. J. A. Venn. Part 2: From 1752 to 1900 . Vol. 5: Pace-Spyers. Pp. iv +614 . (Cambridge: At the University Press, 1953.) $£ 10$ 10s. net.

THE first volume of "Alumni Cantabrigienses" appeared in 1922. The monumental task undertaken by the late Dr. John Venn and his son, Dr. J. A. Venn, now president of Queens' College, Cambridge, is drawing near completion. Of the six volumes allotted by Dr. Venn to Part 2, for which he has been alone responsible, only one further volume now remains to be published.

The present volume naturally repeats the main features of the previous volumes of Part 2: the great preponderance of clerics among the University graduates of the years $1750-1900$ remains very marked. Many clergymen had distinguished careers, like George Augustus Selwyn, first Bishop of New Zealand, in memory of whom Selwyn College was founded. Others like Stanley P. Smith, one of the famous "Cambridge Seven", Charles Simeon, leader of an Evangelical group, and William Paley, of the "Evidences of Christianity", are remembered for different reasons. Curious side-lights are given on the lives and views of others: H. T. Robins, being suspicious of the wine he was preparing for communion, saved the lives of one or more of his congregation, but lost his own, by tasting it: it proved. to be caustic soda.

Of the many distinguished scholars, only a few can be mentioned: W. Robertson Smith, a member of the Old Testament Revision Committee in 1875, E. H. Palmer, professor of Arabic, murdered by Arabs when on a secret mission in Fgypt, Adam Sedgwick and William Ridgeway were all colourful personalities, as also was Richard Porson, who was regius professor of Greek for sixteen years but never resided in Cambridge during the tenure of his chair. Of a different type was S. G. Phear, Master of Emmanuel College, who retired from the mastership after twenty-four years of office-an action described by another and older head of a college as "a most immoral proceeding". Of schoolmasters, the names of Sanderson of Oundle and T. E. Page of Charterhouse stand out; Samuel Parr, who "flogged after the old fashion", H. S. S. Salt of Eton, who renounced flesh food, declaring his colleagues to be "but cannibals in cap and gown", and J. P. Plumptre, also of Eton, who stigmatized Catholic emancipation as "the wickedest thing since the Crucifixion", are mentioned here as typifying a different class of schoolmaster.

Politicians play a prominent part in the list of biographies. It may suffice here to mention three Prime Ministers of Britain-Pitt, Lord Palmerston and Perceval, who was assassinated in the lobby of the House of Commons-and two Commonwealth Premiers-Smuts and W. P. Schreiner. Another 